Гамидов А.М. Проблемы формирования и реализации правовой позиции стороны защиты в уголовном процессе

УДК 343.122

DOI: $10.21779 / 2500-1930-2018-33-2-83-88$

\title{
А.М. Гамидов
}

\section{Проблемы формирования и реализации правовой позиции стороны защиты в уголовном процессе}

Дагестанский государственный университет; Россия, 367001; 2. Махачкала, ул. М. Гаджиева, 43a; crimprocces@mail.ru

В статье рассматриваются вопросы соотношения процессуальных сил стороны защиты и стороны обвинения в уголовном процессе при продвижении своей правовой позиции, обосновывается необходимость уменьшения обвинительного уклона в нём. Автор рассматривает два механизма осуществления этой задачи: посредством добавления новых процессуальных возможностей стороне защиты в процессе доказывания для обеспечения необходимых возможностей формирования правой позиции по уголовному делу и посредством расширения круга субъектов, допускаемых в качестве защитника обвиняемого.

Ключевые слова: прочессуальные полномочия, защитник, доказательства, состязательность, правовая позищия, адвокатское расследование, субъект защиты, адвокат.

Важнейшими задачами уголовного судопроизводства являются установление истины по уголовному делу и решение вопроса о виновности лица, которому предъявлено обвинение. В этих целях с одной стороны - стороны обвинения - строго очерченный в уголовно-процессуальном законе круг субъектов для установления события преступления, обстоятельств дела и фактов, имеющих отношение к делу, и изобличения лица или лиц, виновных в совершении преступления, осуществляет уголовное преследование, предварительное следствие и дознание. С другой стороны - стороны защиты - адвокат в целях охраны лица от незаконного обвинения и осуждения, доказательства невиновности подозреваемого или обвиняемого и необходимости его реабилитации, либо освобождения его от уголовной ответственности и наказания, либо применения к подзащитному минимальной меры наказания участвует в процессе доказывания и иным образом оказывает юридическую помощь подзащитному.

В первом случае указанные цели достигаются путём возбуждения уголовного дела в установленном УПК РФ порядке, предъявления обвинения, производства следственных действий с соблюдением порядка фиксации и удостоверения их хода и результатов, собирания доказательств, передачи дела в суд и участия в судебном разбирательстве. Во втором случае цели защиты достигаются консультированием подзащитного, возможностью присутствия адвоката на допросе и при производстве следственных действий, обжалованием действий и решений участников уголовного процесса со стороны обвинения, представлением сведений, документов и предметов следователю, дознавателю и суду для приобщения к уголовному делу в качестве доказательств, участием стороны защиты в судебном разбирательстве.

Таким образом, исходя из подсчёта функциональных возможностей сторон в продвижении своей правовой позиции, может показаться, что силы стороны обвинения и 
Гамидов А.М. Проблемы формирования и реализации правовой позиции стороны защиты в уголовном процессе

стороны защиты равны, а уголовный процесс отвечает принципу состязательности. Но в свете того, что оправдательных приговоров в России выносится всего 0,4 \% [1], то возможной причиной могут быть отдалённость и слабый доступ стороны защиты к формированию доказательной базы. Следовательно, выводы о равенстве и состязательности сторон ставятся под сомнение.

Такое предположение подтверждается и следующими правовыми реалиями: участники со стороны обвинения самостоятельны в производстве следственных действий, имеют право самостоятельно собирать сведения об обстоятельствах, имеющих значение для дела, собственными постановлениями приобщать их к уголовному делу в качестве доказательств, имеют право допрашивать свидетелей, осуществлять приводы свидетелей, обвиняемого, потерпевшего и другие процессуальные полномочия, т. е. к моменту судебного разбирательства они имеют совершенную, в рамках их возможностей, правовую позицию. Действия же стороны защиты аналогичной регламентации в законе не находят, причём добытые сведения и предметы могут получить статус доказательств только в случае удовлетворения соответствующего ходатайства стороны о приобщении их к делу. К тому же обязанность лица, которому известны какие-либо обстоятельства, имеющие значение для уголовного дела, давать показания защитнику и вовсе не предусмотрена, а опрос лица с его согласия процессуально не закреплён и соответственно процессуальной силы не имеет и равнозначен доверительной беседе. И в обоих случаях защитнику необходимо заявлять ходатайство перед судом, следователем или дознавателем о допросе этих лиц в качестве свидетелей по делу. Кроме того, закрепив в ч. ст. 86 за органами государственной власти и органами МСУ, общественными объединениями и организациями обязанность предоставлять по требованию защитника справки, характеристики и иные документы, УПК не определил сроки, в течение которых такие сведения должны быть предоставлены, фактически допустив запоздалую их выдачу.

В связи с этим возникает вопрос: достаточны ли права защитника, закреплённые в УПК, для признания уголовного процесса соответствующим п. 3 ст. 123 Конституции РФ, в котором говорится, что судопроизводство осуществляется на основе состязательности и равноправия сторон? Хватает ли процессуальных возможностей у стороны защиты для формирования чёткой и обоснованной правовой позиции, а также её продвижения и реализации в суде?

Многие учёные считают необходимым расширить частное начало в уголовном процессе и уменьшить обвинительный уклон в нём. В частности, в юридической литературе нередко встречаются вопросы о предоставлении защитником доказательств как в суде, так и на стадии предварительного расследования. Часты споры о том, является ли защитник самостоятельным субъектом доказывания, или он - всего лишь ходатай? С нашей точки зрения, защитник не имеет достаточно процессуальных возможностей для того, чтобы отнести его к числу первых.

Битокова М.Х. считает, что представление защитником полученных доказательств стороне обвинения не отвечает принципу состязательности, и необходимо закрепить возможность представления их защитником только суду в ходе судебного следствия [2, c. 12]. Действительно, законом закреплено, что функции обвинения и защиты разделены и не могут быть возложены на один и тот же орган или должностное лицо. Но помимо этого, для экономии времени было бы целесообразнее включить нормы, позволяющие проводить защитнику собственное расследование в стадии досудебного производства. Но внедрение элементов адвокатского расследования, по мнению Белкина, будет иметь и неблагоприятные последствия: «действия, совершаемые защитником в 
Гамидов А.М. Проблемы формирования и реализации правовой позиции стороны защиты в уголовном процессе

процессе параллельного расследования, будут являться помехой для работы следователя, поскольку способны создавать предпосылки для уничтожения следов преступления, сокрытия какой-либо информации, подтверждающей справедливость выводов следователя о виновности обвиняемого. Это, в свою очередь, затруднит процесс установления в суде истины по уголовному делу или вообще сделает это невозможным».

Во избежание таких ситуаций нам представляется целесообразным установление повышенных, по сравнению с правилами для органов предварительного расследования, требований законности и допустимости к процессу собирания, удостоверения, фиксации и закрепления доказательств защитником. Это необходимо также и потому, что данные защиты на пути продвижения к получению закреплённого законом статуса доказательств имеют большой шанс затеряться. Причём полученные законным путём достоверные данные, которые по тем или иным причинам, ввиду запутанности и сложности дела противоречат доказательственным данным обвинения, отметаются в большинстве случаев в зале судебного заседания. И уже здесь установление таких мер к обеспечению соответствия доказательств требованию относимости и допустимости позволит закрепить за судом обязанность удовлетворять ходатайства защитника о приобщении к материалам уголовного дела предметов и документов в качестве доказательств. Это, с другой стороны, стало бы и защитой от бюрократизма в судебной системе, причём, предоставив возможность собирать и закреплять в установленном порядке любые доказательства в судебном процессе, законодатель поспособствует повышению транспарентности уголовного судопроизводства и вероятности вынесения справедливого решения.

Во-вторых, имея процессуальную заинтересованность в исходе дела, зачастую сторона обвинения может безразлично относиться к выявлению фактов, говорящих о невиновности лица, упускать и не закреплять такие данные, причём и те, которые были получены ими в силу их правового положения, когда такие же данные получить простому защитнику не предоставляется возможности, а ходатайство защитника участнику со стороны обвинения о проведении следственных действий не удовлетворяется. И это, действительно, имеет место быть на практике: следователями и дознавателями удовлетворяется не более 38 \% ходатайств защитников. В этом случае, чтобы данные не утерялись, нужно, чтобы той же процессуальной силой, но с противоположным интересом, эти данные подхватывались. Брянская Е.В., и Шишкина Н.Э. и вовсе считают, что «полномочия защитника в процессе доказывания по уголовным делам должны быть настолько детально регламентированы, что позволили бы освободить органы уголовного преследования от собирания доказательств защиты» [3]. И с этой точки зрения мы считаем необходимым дать больше доказательственных возможностей стороне защиты, закрепить процессуальный порядок получения доказательств и предоставить право передавать эти сведения в качестве доказательств непосредственно защитнику.

Также негативно влияет на формирование правовой позиции стороны защиты несвоевременное предоставление ей материалов дела для ознакомления. По нашему мнению, необходимо предоставить ей время в течение 3 суток для формирования и изъявления ходатайств после ознакомления с материалами дела. Кроме того, мы присоединяемся к мнению Трунова И.Л., который предлагает установить необходимость составления защитительного заключения по окончании адвокатского расследования $[4$, с. 6], и к мнению Мельникова В.Ю., который предлагает дополнить раздел VIII «Предварительное расследование» УПК РФ отдельной главой «Адвокатское расследование» [5]. 
Гамидов А.М. Проблемы формирования и реализации правовой позиции стороны защиты в уголовном процессе

Также мы разделяем точку зрения Щиголева Ю.В., что уголовное дело не может быть рассмотрено судом окончательно, если на запрос адвоката от специалиста или должностного лица не получен ответ, содержащий значимые для дела фактические данные [6, с. 54] В связи с этим мы считаем целесообразным дополнить п. 3 ч. 3 ст. 86 УПК РФ следующим положением: «Государственные органы, органы местного самоуправления, общественные объединения и организации, получившие запрос от защитника по уголовному делу, обязаны предоставлять запрашиваемые документы или их копии в течение 10 суток», тем самым предоставив стороне защиты гарантию своевременного получения необходимых доказательств, и следовательно, своевременного формирования правовой позиции по уголовному делу.

Однако более существенную помощь в формировании правовой позиции стороне защиты может оказать проведение судебной экспертизы, результаты которой приобретут статус доказательств без каких-либо сомнений в достоверности со стороны суда и без предвзятости. А такое возможно лишь в том случае, если экспертиза будет проведена именно государственным экспертным учреждением. Если в случае с предоставлением защитнику возможности собирать и приобщать к делу доказательства и допрашивать свидетелей у некоторых учёных возникают вопросы, касающиеся беспристрастности защитника и недопущения фальсификации им доказательств, то в случае с предоставлением защитнику права назначения экспертизы наравне с органами предварительного расследования и судом риск такого введения суда в заблуждение практически сведён к нулю. К слову, о необходимости реформирования российского уголовного процесса посредством закрепления этого права за защитником говорит Бахтадзе Г.Э., предлагая перенять такую норму из уголовного процесса Грузии [7].

Косвенно с проблемой реализации правовой позиции связана проблема компетенции и статуса субъекта защиты. По действующему законодательству защитником в уголовном судопроизводстве может быть только адвокат. Исключение составляют случаи осуществления защиты иными лицами при производстве у мирового судьи. По этому вопросу высказывался Конституционный Суд РФ в своём постановлении от 28 января 1997 года: «Гарантируя право на получение именно квалифицированной юридической помощи государство должно, во-первых, обеспечить условия, способствующие подготовке квалифицированных юристов для оказания гражданам различных видов юридической помощи, в том числе в уголовном судопроизводстве, и, вовторых, установить с этой целью определенные профессиональные и иные квалификационные требования и критерии. Участие в качестве защитника в ходе предварительного расследования дела любого лица, по выбору подозреваемого или обвиняемого может привести к тому, что защитником окажется лицо, не обладающее необходимыми профессиональными навыками, что несовместимо с задачами правосудия и обязанностью государства гарантировать каждому квалифицированную юридическую помощь» [8, с. 92].

Такая позиция законодателя нами считается необоснованной. Необходимо предоставить равный доступ к осуществлению защиты всем гражданам, причём возможность негативных последствий в этом случае, от которых и пытается защитить интересы обвиняемого и правосудия в целом законодатель, обязуя защитника быть адвокатом, являются риском непосредственно самого обвиняемого и в данной ситуации лишь предоставляет расширенную возможность на защиту, возможность выбора обвиняемым защитника, хоть и не имеющего статуса адвоката, но такого, в чьих правозащитных или дедуктивных, доказательственных способностях он уверен больше, чем в возможности защитить его от необоснованного осуждения профессиональным адвокатом. Причём в пользу такой позиции в самом же Конституционном Суде РФ высказывались четверо

86 Вестник Дагестанского государственного университета. Серия 3. Общественные науки. 2018. Том. 33. Вып. 2 
Гамидов А.М. Проблемы формирования и реализации правовой позиции стороны защиты в уголовном процессе

судей из девяти, изложив по вышеназванному делу особые мнения. Могут ли пострадать интересы правосудия? Естественно, могут, как и в том случае, если помощь обвиняемому будет оказывать инертный или недостаточно компетентный адвокат.

Однако законодатель, призывая защитника быть адвокатом, в некоторых случаях обязывает адвоката участвовать в уголовном процессе, даже если обвиняемый от этой помощи отказывается. Мы согласны с мнением Стройковой А.С., которая считает, что «эти ограничения нередко создают на стадии предварительного расследования ситуации, когда обвиняемый вынужден доверить защиту своих интересов нежелательному для него лицу, от услуг которого он в суде отказывается, либо, видя формальное к себе отношение, вынужден привлекать иных лиц, желая обеспечить эффективность осуществляемой в отношении себя защиты» [9, с. 3]. К тому же предоставление обвиняемому права на допуск судом по его ходатайству наряду с защитником и других лиц на стадии судебного разбирательства и ограничение этого права на стадии предварительного расследования, как минимум, не логичны. И потому необходимо исследовать эту проблему диалектическим путём, как это делает Дежнев А.С., видя в формальной реализации права на квалифицированную юридическую помощь игнорирование социальной сущности человека и нравственных устоев общества [10].

И здесь мы поддерживаем мнение Пчелинцева М.И., который считает, что институт адвокатуры должен быть пересмотрен в плане ответственности защитника, так как существующая на данный момент ответственность защитника только перед своим подзащитным и частично перед адвокатским сообществом - неэффективна [11, с. 263].

Таким образом, мы считаем необходимым расширить частные начала в уголовном процессе, предоставить большие возможности стороне защиты на стадии досудебного производства и судебного разбирательства, а также соответствующим образом регламентировать порядок такой деятельности. Кроме того, считаем необходимым допускать в качестве защитника любое дееспособное лицо, достигшее 18-летнего возраста, о котором будет ходатайствовать подозреваемый или обвиняемый.

\section{Литература}

1. http://www.bbc.com/russian/russia/2015/01/150120_markin_acquittal_rate_court_r ussia.

2. Битокова M.X. Право собирания доказательств защитником и его осуществление в уголовном судопроизводстве: автореф. дис. ... канд. юр. наук. - М., 2008.

3. Брянская E.B., Шишкина Н.Э. Особенности защиты в процессе доказывания при рассмотрении уголовных дел // Сибирский юридический вестник. - 2015. - № 4.

4. Трунов И.Л. Расширение состязательности уголовного процесса на стадии предварительного расследования в свете судебной реформы // Российский судья. 2002. - № 3.

5. Мельников В.Ю. Пробелы в российском законодательстве // Юридический журнал. - 2012. - № 2.

6. Щиголев Ю.В. Является ли задачей защиты установления истины по делу // Адвокатская практика. - 2000. - № 1.

7. Бахтадзе Г.Э. Необходимость наделения стороны защиты правом назначения судебных экспертиз // Вестник Самарского государственного университета. - 2014. № 11-2.

8. http://www.consultant.ru/document/cons_doc_LAW_13370/ca1820d99f2c758e82d $835816 \mathrm{~b} 28 \mathrm{c} 0 \mathrm{a} 34417 \mathrm{dc} 33 /$. 
9. Стройкова А.C. К вопросу о процессуальном статусе защитника обвиняемого в российском уголовном процессе // Вестник Адыгейского государственного университета. Серия 1: Регионоведение: философия, история, социология, юриспруденция, политология, культурология. - 2008. - № 2.

10. Пчелинщев М.И. Защитник в уголовном судопроизводстве: актуальность исследования // Проблемы современной науки и образования. -2014 . - № 7 .

11. Дежнев А.С. Привлечение в качестве защитников по уголовным делам близких родственников и иных лиц // Вестник Омского университета. Сер. Право. - 2012. № 3.

Поступила в редакиию 26 января 2018 г.

UDC 343.122

DOI: $10.21779 / 2500-1930-2018-33-2-83-88$

\title{
Problems of formation and implementation of legal position of the defence in the criminal process
}

\author{
A.M. Gamidov \\ Dagestan State University; Russia, 367001, Makhachkala, M. Gadzhiev st., 43a; \\ crimprocces@mail.ru
}

The article discusses the ratio of the procedural powers of the defense and the prosecution in criminal proceedings in promoting its legal position, reduce the necessity accusatory in it. The author considers two mechanisms of accomplishing this task: by adding new procedural options to the defense evidence in the process to provide the necessary possibilities of forming the right position on the criminal case, and by expanding the range of subjects allowed as a defender of the accused.

Keywords: procedural powers, defender, evidence, competitiveness, legal position, advocates investigation, the subject of investigation, advocate.

Received 26 January, 2018 